\title{
Sudden Cardiac Death in Dakar: Epidemiological and Anatomo-Pathological Characteristics
}

\author{
El Hadji Oumar Ndoye1* ${ }^{*}$, Amadou Mouctar Diallo², Ibou Thiam¹, Mouhamed Manibiliot Soumah', \\ Sidy Ahmed Dia ${ }^{1}$, Mor Ndiaye ${ }^{1}$
}

${ }^{1}$ Forensic and Labor Medicine Department, Cheikh Anta Diop Dakar University (UCAD), Dakar, Senegal

${ }^{2}$ Forensic Department, Ignace Deen Hospital, Conakry, Guinea

Email: *omar.ndoy@yahoo.com

How to cite this paper: Ndoye, E.H.O., Diallo, A.M., Thiam, I., Soumah, M.M., Dia, S.A. and Ndiaye, M. (2019) Sudden Cardiac Death in Dakar: Epidemiological and Anatomo-Pathological Characteristics. Forensic Medicine and Anatomy Research, 7, 51-61.

https://doi.org/10.4236/fmar.2019.73009

Received: June 17, 2019

Accepted: July 28, 2019

Published: July 31, 2019

Copyright $\odot 2019$ by author(s) and Scientific Research Publishing Inc. This work is licensed under the Creative Commons Attribution International License (CC BY 4.0).

http://creativecommons.org/licenses/by/4.0/

cc) (i) Open Access

\begin{abstract}
Sudden cardiac death (SCD) generally refers to sudden cardiovascular death of a person with or without pre-existing heart disease. This is a retrospective study conducted at the Department of Anatomy and Pathological Cytology at Aristide Le Dantec Hospital in Senegal. This study covers a period of 7 years from January $1^{\text {st }}, 2000$ to December $31^{\text {st }}, 2006$. During this 7 -year period we collected 235 cases of sudden cardiovascular death out of a total of 3717 forensic autopsies, representing a frequency of $6.32 \%$. Sudden cardiovascular deaths accounted for $75.3 \%$ of all 312 sudden deaths. $96.1 \%$ were black compared to $3.9 \%$ Caucasians. The average age of the patients was 46.86 years with extremes ranging from 17 to 86 years. The most affected age group was between 50 - 59 years old, representing $23.4 \%$ of the cases. The sex ratio was 4.3 in favour of men. Men aged 50 - 59 were the most affected, while women were more affected in the 20 - 29 age group. Cardiomyopathies constituted 54.9\% with $90 \%$ of dilated cardiomyopathies of which $75 \%$ were male and $10 \%$ of hypertrophic cardiomyopathies more frequent also in men. Valvulopathies came in $3^{\text {rd }}$ position with $3.4 \%$ of the cases and in $75 \%$ of the cases they were poly-valvulopathies. Atherosclerosis was incriminated in $2.5 \%$ of the cases and aortic localization was the most represented. Aortic dissection was implicated in 6 cases out of 235 or $2.5 \%$. It was isolated in 4 cases (without other cardiac conditions), and in the other 2 cases it was accompanied by other cardiac lesions including hypertrophy, pericarditis and endocarditis. The other causes found were interauricular communication $(\mathrm{n}=1)$ and pericarditis $(n=2)$. Sudden cardiovascular death is a major global public health problem. The lack of epidemiological data on sudden death in Africa motivated our work, which led us to note that $75.3 \%$ of all sudden deaths in adults were of cardiovascular origin.
\end{abstract}




\section{Keywords}

Sudden Cardiac Death, Forensic Medicine, Autopsy

\section{Introduction}

Analyses of disease progression patterns conducted at the end of the last millennium predicted an increased global rate of heart disease by 2020 [1] [2]. These predictions have already been confirmed in the first decade of the new millennium. In a reversal of trends, the largest increases in the prevalence of diabetes and coronary heart disease are observed in developing countries [3]. An important consequence of this rapidly growing population of patients with coronary heart disease and heart failure will be an increasing rate of sudden cardiac death.

Sudden death is a heartbreaking event that leaves a sense of weakness; not only among patients, but often also among medical and paramedical staff, whose support is sometimes too late.

Sudden cardiac death (SCD) generally refers to sudden cardiovascular death of a person with or without pre-existing heart disease. The specificity of this definition varies depending on whether the event was observed or not [2].

Indeed, according to an American study [4], sudden cardiac mortality represents between 300,000 and 400,000 cases of death per year, it is estimated at around 70,000 deaths per year in France [5].

In Cameroon, the rate of sudden cardiac death is 31.3 cases per 100,000 person-years [6]. Therefore, sudden cardiac death should be considered as a global public health problem.

Underestimated in Africa and Senegal, sudden death is increasingly becoming part of our daily lives. The lack of data on sudden cardiac death in Africa and particularly in Senegal underlies the relevance of this study whose objective is to determine its epidemiological and anatomopathological characteristics in Senegal and then to suggest recommendations for its prevention.

\section{Methodology}

\subsection{Place of Study and Type of Study}

This is a retrospective study conducted at the Department of Anatomy and Pathological Cytology at Hospital Aristide Le Dantec in Senegal. This study covers a period of 7 years from $1^{\text {st }}$ January 2000 to $31^{\text {st }}$ December 2006. It should be noted that in Senegal, most forensic and medical autopsies are performed in the pathological anatomy department of Hospital Le Dantec.

\subsection{Population of Study}

During this period, we compiled 235 cases of the sudden death of cardiovascular 
origin from 3717 forensic autopsy reports performed in the unit.

It should be noted that the dissection of the coronaries was carried out with great difficulty due to a lack of equipment in the department.

\subsection{Inclusion Criteria}

Included in this study were autopsy cases of subjects over 15 years of age who suffered sudden, unexpected and rapid natural death.

\subsection{Exclusion Criteria}

Excluding cases of violent deaths (suicide, road accidents), sudden deaths of non-cardiac origin, intoxication and putrefaction.

\subsection{Data Analyses}

All these data were collected from patient records and entered on an Excel spreadsheet and analyzed using software such as SSPI, Excel.

\subsection{Ethical Considerations}

Our study was carried out in compliance with the rules of ethics and confidentiality regarding the identity and personal information of deceased persons.

\section{Results}

-Frequency:

During this 7-year period we collected 235 cases of sudden cardiovascular death out of a total of 3717 forensic autopsies, representing a frequency of $6.32 \%$.

Sudden cardiovascular deaths represented $75.3 \%$ of all sudden deaths, which totaled 312 .

-Race:

The black race was the most represented with $96.1 \%$ against 3.9\% Caucasians.

-Age:

The average age of the patients was 46.86 years with extremes ranging from 17 to 86 years.

The most affected age group was between 50 - 59 years old, representing $23.4 \%$ of the cases.

-Sex:

The sex ratio was 4.3 in favour of men.

Men aged 50 - 59 were the most affected, while women were more affected in the 20-29 age group.

The average age of men was 49.92 years, while it was 35.63 years for women. (See Figure 1)

-Etiologies:

- Cardiomyopathies constituted $54.9 \%(\mathrm{n}=129)$ with $90 \%$ of dilated cardiomyopathies $(n=116)$ of which $75 \%$ are male $(n=87)$ and $10 \%$ of hypertrophic cardiomyopathies also more frequent in males. 
These cardiomyopathies were much more frequent in the 20 - 29 age group for women $(n=12)$ while for men they were more frequent in the 50 - 59 age group $(\mathrm{n}=21)$. (See Table 1$)$

- Myocardial infarction was the $2^{\text {nd }}$ cause with $35.3 \%$ of cases $(n=83)$. In $89 \%$ of the cases, the infarction was accompanied by hypertrophy of the heart ( $\mathrm{n}=$ 74 ) and in $11 \%$ of the cases it was associated with atherosclerosis of the coronary arteries.

The majority of the cases were male, i.e. 90.3\% $(n=75)$, and the 50-59 age group was the most affected. (See Table 2)

- Valvulopathies came in $3^{\text {rd }}$ position with $3.4 \%$ of the cases $(n=8)$ and in $75 \%$ of the cases they were poly-valvulopathies.

- Atherosclerosis was implicated in $2.5 \%$ of cases $(n=6)$ and aortic localization was the most represented.

- Aortic dissection was implicated in 6 cases out of 235 or $2.5 \%$. It was isolated in 4 cases (without other cardiac conditions), and in the other 2 cases it was accompanied by other cardiac lesions including hypertrophy, pericarditis and endocarditis.

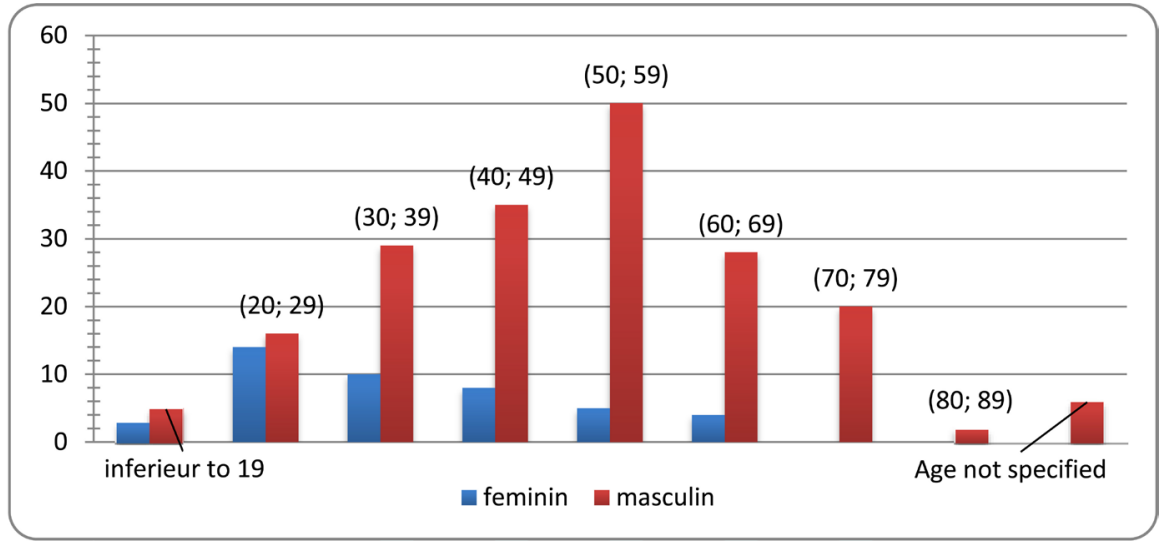

Figure 1. Distribution by age and sex.

Table 1. Distribution of cardiopathies by age and sex.

\begin{tabular}{cccc}
\hline \multicolumn{1}{c}{ Sex } & Female & Male & Total \\
\hline Age & - & 3 & 3 \\
Inferior or equal to 19 years & 12 & 11 & 23 \\
$(20 ; 29)$ & 8 & 16 & 24 \\
$(40 ; 39)$ & 5 & 20 & 25 \\
$(50 ; 59)$ & 3 & 21 & 24 \\
$(60 ; 69)$ & 1 & 15 & 16 \\
$(70 ; 79)$ & - & 10 & 10 \\
80 years and more & - & 1 & 1 \\
Age not specified & - & 3 & 3 \\
Total & 29 & 100 & 129 \\
\hline
\end{tabular}


Table 2. Distribution of myocardial infarction by age.

\begin{tabular}{cccc}
\hline Age & $\begin{array}{c}\text { Myocardial } \\
\text { infarction (MI) }\end{array}$ & $\begin{array}{c}\text { Myocardial infarction } \\
\text { with Coronary } \\
\text { atherosclerosis. }\end{array}$ & $\begin{array}{c}\text { Myocardial infarction without } \\
\text { coronary status specification }+ \\
\text { Hypertrophy of the heart }\end{array}$ \\
\hline Inferior to 19 years & - & - & 0 \\
$(20 ; 29)$ & - & 12 & 5 \\
$(30 ; 39)$ & 2 & 14 & 12 \\
$(40 ; 49)$ & 5 & 22 & 16 \\
$(50 ; 59)$ & - & 13 & 27 \\
$(60 ; 69)$ & 2 & 6 & 13 \\
$(70 ; 79)$ & - & 1 & 1 \\
80 years and more & - & 1 & 83 \\
Age not specified & 9 & 74 & \\
Total & & & 1 \\
\hline
\end{tabular}

- The other causes found were:

- Interauricular communication $(\mathrm{n}=1)$;

- Pericarditis $(\mathrm{n}=2)$.

\section{Discussion}

The frequency of $6.32 \%$ of sudden cardiovascular death in our forensic autopsy series performed is slightly higher than the ones found in Nigeria (4.3\%) [7] and Paris (5.34\%) [8]. However, it is significantly lower than the ones found in Lyon, Saint-Etienne (8.4\%) [9] and Côte d'Ivoire (9.7\%) [10]. This frequency has tripled in 20 years in Dakar from 2.14\% [11] to 6.32\%.

The variability in the figures is largely related to the criteria taken into account by the authors; because the time between the onset of symptoms and death is not unambiguous, but also by a lack of proper resuscitation observed in our health facilities and the inadequate follow-up of patients with heart disease. The early occurrence of sudden death in developing countries can be explained by the low socio-economic level, unfavourable local health conditions and the absence of a policy for the detection of cardiovascular diseases.

Almost all of our cases (94.1\%) were Black, which means that the sudden death of cardiovascular origin also affects black people living in Africa.

According to age, $58.3 \%$ of cases concern the active population (30 - 59 years old). This rate is superimposed on the rate obtained in Nigeria [7]. This could be explained by the frequency of the heart diseases in question, which changes significantly from the age of 35 [12], particularly hypertrophic cardiomyopathy and high blood pressure.

Indeed, these results are consistent with the literature data in the Third World as in Tunisia with 55.75 years and in Saudi Arabia with 60 years. On the other hand, the average age is slightly lower than the one in developed countries (in 
France and according to the centre of expertise on sudden death, the average age is 65 years).

The rate of sudden cardiac death increases significantly with age, regardless of gender or race. For example, the annual rate for 50-year-old men is about 100 per 100,000 people compared to 800 per 100,000 for 75 -year-old men [13]. Although sudden cardiac death increases with age, the proportion of sudden deaths is higher in younger age groups [14] [15] where the socio-economic impact is greater.

The male predominance is clear in our series $(81 \%)$ as in the literature as a whole [16]-[22]. This may be explained by the male frequency for hypertrophic cardiomyopathies [9] and by hormonal factors according to the study by Framingham [18] and Ajayi A.A. et al. [23].

Cardiovascular causes account for $75.3 \%$ of the sudden death aetiologies in our study. This predominance of heart disease corroborates the data in the literature [24] [25] [26] [27]. The prevalence of cardiomyopathies found in our study is not superimposed on the one found in developed countries where atheroembolic coronary heart disease predominates [9] [28]. This is due to the early detection of these cardiomyopathies in these countries and their adequate management. The prevalence of CMD is about $0.04 \%$ and is therefore comparable to that of HCM [29]. CMD is a common phenotype for many non-family and family (genetic) conditions [30]. Dilated cardiomyopathy is a phenotype common to a multitude of genetic disorders and non-family diseases. Changes in the titin gene, which is a structural protein of the sarcomere, have recently been recognized as the main family cause [30] [31] [32].

Hypertrophic cardiomyopathy (HCM) is a myocardial disease of genetic origin, defined by the presence of asymmetric thickening of the left ventricular wall (LV), without dilation of its cavity and in the absence of other cardiac or systemic disease that may explain the severity of the hypertrophy of the heart muscle (e.g. high blood pressure, aortic stenosis) [33]. It affects both sexes and all ethnic groups, with a prevalence of 1:500, or $0.2 \%$ of the general population [34].

This figure contrasts sharply with the low incidence of HCM detected in clinical practice, suggesting that most individuals remain asymptomatic and therefore under-diagnosed.

In our study, myocardial infarction was involved in $35.3 \%$ of the cases. This rate was close to the literature where the frequency of myocardial infarction is between $11 \%$ and 33\% [35] [36] [37] [38] [39] as well as the other causes. The main clinical outcome associated with sudden cardiac death is coronary artery disease and approximately $80 \%$ of sudden cardiac deaths are attributed to this condition [40] [41] [42] [43] [44]. Coronary heart disease is the most common subjacent substrate in the Western world, accounting for about $75 \%$ of sudden cardiac deaths [45] [46] [47]. Cardiomyopathies (dilated, hypertrophic and arrhythmogenic right ventricular cardiomyopathy) and primary electrical disorders related to channelopathies account for most of the rest. The high 
frequency of sudden coronary death is probably due to bad lifestyle habits, neglected and delayed consultation when patients experience chest pain. Sudden death may be the first symptom of coronary artery disease.

The $2.5 \%$ rate of aortic dissection found in our study was relatively lower than the one found by Fornes, P. et al. in France (3.01\%) [29] and slightly higher than the one found by Loire, R. and Tabib, A. [41] who reported a percentage of $1.29 \%$. This could be explained by a difference in the size of the samples. Its occurrence in the young population suggests in the first place a subjacent pathology, in particular an inherited dystrophic disorder such as Marfan syndrome or congenital disorders such as coarctation of the aorta or bicuspid aortic [48] [49].

According to Januzzi et al. [50], who studied the characteristics of aortic dissections in subjects under 40 years of age, Marfan syndrome represents the first risk factor, found in $50 \%$ of the cases, followed by high blood pressure (34\% of the cases). Marfan syndrome is an autosomal, monogenic disease of connective tissue resulting from a fibrillin abnormality. Molecule of the extracellular matrix.

The choice of the study period between 2000 and 2006 is the main limitation of our study. In fact, this period does not tell us about the most recent data on the most recent sudden cardiac deaths (2007 to 2018). A comparison with current data should be made to know the true incidence of sudden cardiac death.

\section{Conclusions}

Sudden cardiovascular death is a major global public health problem. The lack of epidemiological data on sudden death in the world and especially in Africa has motivated our work, which has shown that $75.3 \%$ of all sudden deaths in adults were of cardiovascular origin.

These data have prompted us to make the following recommendations:

- an improvement of the equipment of emergency services and good training of the medical staff working in these facilities;

- an awareness-raising campaign on first aid procedures and the training of general practitioners in the field of cardiology;

- the value of genetic screening limited to identifying members of an affected family who have not yet developed myocardial hypertrophy and follow-up;

- the participation of forensic medicine in the development of all diagnostic procedures for sudden deaths.

\section{Conflicts of Interest}

The authors declare no conflicts of interest regarding the publication of this paper.

\section{References}

[1] Murray, C.J. and Lopez, A.D. (1997) Alternative Projections of Mortality and Disability by Cause 1990-2020: Global Burden of Disease Study. The Lancet, 349, 
1498-1504. https://doi.org/10.1016/S0140-6736(96)07492-2

[2] Murray, C.J. and Lopez, A.D. (1997) Mortality by Cause for Eight Regions of the World: Global Burden of Disease Study. The Lancet, 349, 1269-1276. https://doi.org/10.1016/S0140-6736(96)07493-4

[3] Fishman, G.I., Chugh, S., DiMarco, J.P., Albert, C.M., Anderson, M.E., Bonow, O.R., Buxton, A.E., Chen, P.-S., Estes, M., Jouven, X., Kwong, R., Lathrop, D.A., Mascette, A.M., Nerbonne, J.M., O’Rourke, B., Page, R.L., Roden, D.M., Rosenbaum, D.S., Sotoodehnia, N., Trayanova, N.A. and Zheng, Z.-J. (2010) [Rapport de prévision et de prévention de la mort subite d'origine cardiaque tiré d'un atelier de la National Heart, Lung and Blood Institute et de la Heart Rhythm Society]. Circulation, 122, 2335-2348. https://doi.org/10.1161/CIRCULATIONAHA.110.976092

[4] Okrainec, K., Banerjee, D.K. and Eisenberg, M.J. (2004) Coronary Artery Disease in the Developing World. American Heart Journal, 148, 7-15. https://doi.org/10.1016/j.ahj.2003.11.027

[5] Nichol, G., Thomas, E., Callaway, C.W., Hedges, J., Powell, J.L., Aufiderheide, T.P., Rea, T., Lowe, R., Brown, T., Dreyer, J., Davis, D., Idris, A. and Stiell, I. (2008) Regional Variation in Out-of-Hospital Cardiac Arrest Incidence and Outcome. Journal of the American Medical Association, 300, 1423-1431. https://doi.org/10.1001/jama.300.12.1423

[6] Talib, A., et al. (1998) Anatomie pathologique de la mort subite d'origine cardio-pulmonaire. Meditions, Lyon.

[7] Bonny, A., Ngantcha, M., Saka, C., Wa, J. and Fonga, R. (2016) Epidémiologie de la mort subite cardiaque au Cameroun. Revue d'Epidémiologie et de Santé Publique, 64, 173-213. https://doi.org/10.1016/j.respe.2016.06.108

[8] Rotini, O., Ajayi, A.A. and Odesanmi, W.O. (1998) Sudden Unexpected Death from Cardiac Causes in Nigerians: A Review of 50 Autopsied Cases. International Journal of Cardiology, 63, 111-115. https://doi.org/10.1016/S0167-5273(97)00274-X

[9] Lecomte, D., Formes, P. and Nicolas, G. (1996) Stressful Events as a Trigger of Sudden Death: A Study of 43 Medico-Legal Autopsy Cases. Forensic Science International, 79, 1-10. https://doi.org/10.1016/0379-0738(95)01873-5

[10] Tabib, A. and Loire, R. (1993) Mort subite cardiaque inattendue et lésions coronaires. A propos de 407 cas sur 1000 décès de moins de 65 ans. Archives des Maladies du Coeur et des Vaisseaux, 86, 401-406.

[11] Yapo, E.H., Botti, K. and Djodjo, M. (2005) Les morts subites de l'adulte a Abidjan: autopsie de 171 cas sur 2ans (2001-2002). Journal de Médecine Légale Droit Medical, 48, 151-158.

[12] Ndiaye, P.D., Sow, M.L., Mendes, V., Mbacke, M.A. and Boye, I. (1982) Approche étiologique des morts médico-légales à Dakar (A propos de 1821 cas d'autopsie judiciaire). Dakar Médical, 27, 111-124.

[13] Olivier, J.P. and GeneroGygay, M. (2000) Epidémiologie de la mort subite du sportif. In: Amoretti, R., Brion, R., Eds., Cardiologie du Sport, 181-187.

[14] Becker, L.B., Han, B.H., Meyer, P.M., Wright, F.A., Rhodes, K.V., Smith, D.W. and Barrett, J. (1993) [Différences raciales dans l'incidence des arrêts cardiaques et de leur survie. Le projet de Chicago du CPR]. The New England Journal of Medicine, 329, 600-606. https://doi.org/10.1056/NEJM199308263290902

[15] Albert, C.M., Chae, C.U., Grodstein, F., Rose, L.M., Rexrode, K.M., Ruskin, J.N., Stampfer, M.J. and Manson, J.E. (2003) [Étude prospective sur la mort subite cardiaque chez les femmes aux États-Unis]. Circulation, 107, 2096-2101. 
https://doi.org/10.1161/01.CIR.0000065223.21530.11

[16] Krahn, A.D., Connolly, S.J., Roberts, R.S. and Gent, M. (2004) Réduction du risque proportionnel de mort subite avec l'âge, implications pour la prévention de la mort subite. American Heart Journal, 147, 837-840.

[17] Dupon, M., Doignon, J., Lazarini, H.J. and Larche-Michel, M. (1990) Mort médico-légale. Statistique de l’institut Médico-légal de Bordeaux 1983-1985. Journal de Medecine Legale, 33, 165-176.

[18] Tokasshiki, T., Muratani, A., Kimura, Y., Muratani, H. and Fukiyama, K. (1999) Sudden Death in the General Population in Okinawa: Incidence and Cause of Death. Japanese Circulation Journal, 63, 37-42.

[19] Schatzkin, A., Cupples, A., Heeren, T., Morelock, S. and Kannel, W.B. (1984) Sudden Death in the Framingham Heart Study: Differences in Incidence and Risk Factors by Sex and Coronary Disease Status. American Journal of Epidemiology, 120, 888-899. https://doi.org/10.1093/oxfordjournals.aje.a113960

[20] Corrado, D., Basso, C., Schiavon, M. and Thiene, G. (1998) Screening for Hypertrophic Cardiomyopathy in Young Athletes. The New England Journal of Medicine, 339, 364-369. https://doi.org/10.1056/NEJM199808063390602

[21] Corrado, D., Thiene, G., Nava, A., Rossi, L. and Pennelli, N. (1990) Sudden Death in Young Competitive Athletes: Clinicopathologic Correlation in 22 Cases. The American Journal of Medicine, 89, 588-596. https://doi.org/10.1016/0002-9343(90)90176-E

[22] Maron, B.J., Shirani, J., Poliac, L.C., Mathenge, R., Roberts, W.C. and Mueller, F.O. (1996) Sudden Death in Young Competitive Athletes. Clinical, Demographic and Pathologic Profiles. Journal of the American Medical Association, 276, 199-204. https://doi.org/10.1001/jama.1996.03540030033028

[23] Niimura, I. and Maki, T. (1989) Sudden Cardiac Death in Childhood. Japanese Circulation Journal, 53, 1571-1580. https://doi.org/10.1253/jcj.53.1571

[24] Ajayi, A.A., Mathur, R. and Halushka, P.V. (1995) Testosterone Increases Human Platelet Thromboxane $\mathrm{A}_{2}$ Receptor Density and Aggregation Responses. Circulation, 91, 2742-2747. https://doi.org/10.1161/01.CIR.91.11.2742

[25] de La Grandmaison, G.L. and Durigon, M. (2001) Mort subite de l'adulte: Etude autopsique de 77 cas entre 1995 et 2000. Journal de Médecine Légale Droit Medical, 44, 588-593.

[26] Murai, T., Baba, M., Ro, A., Murai, N., Matsudo, Y., Takada, A. and Satto, K. (2001) Sudden Death Due to Cardiovascular Disorders: A Review of the Studies on the Medico-Legal Cases in Tokyo. The Keio Journal of Medicine, 50, 175-181. https://doi.org/10.2302/kjm.50.175

[27] Schneider, J. and Bezabih, K. (2001) Cause of Sudden Death in Addis Ababa, Ethiopia. Ethiopian Medical Journal, 39, 323-340.

[28] Sheppard, M. and Davies, M.J. (1998) Practical Cardiovascular Pathology. London: Arnold, 1ere Ed.

[29] Formes, P., Lecomte, D. and Nicolas, G. (1994) Mort subite coronaire extrahospitalière: étude autopsique comparative entre des sujets avec et sans antécédents cardiovasculaires. Archives des maladies du coeur et des vaisseaux, 87, 319-324.

[30] Codd, M.B., Sugrue, D.D., Gersh, B.J. and Melton3rd, L.J. (1989) Epidemiology of Idiopathic Dilated and Hypertrophic Cardiomyopathy. A Population-Based Study in Olmsted County, Minnesota, 1975-1984. Circulation, 80, 564-572.

https://doi.org/10.1161/01.CIR.80.3.564 
[31] Watkins, H., Ashrafian, H. and Redwood, C. (2011) Inherited Cardiomyopathies. The New England Journal of Medicine, 364, 1643-1656. https://doi.org/10.1056/NEJMra0902923

[32] Bozkurt, B., Colvin, M., Cook, J., Cooper, L.T., Deswal, A., Fonarow, G.C., et al. (2016) Current Diagnostic and Treatment Strategies for Specific Dilated Cardiomyopathies: A Scientific Statement from the American Heart Association. Circulation, 134, 579-646. https://doi.org/10.1161/CIR.0000000000000455

[33] LeWinter, M.M. and Granzier, H.L. (2013) Titin Is a Major Human Disease Gene. Circulation, 127, 938-944. https://doi.org/10.1161/CIRCULATIONAHA.112.139717

[34] Maron, B.J., Towbin, J.A., Thiene, G., Antzelevitch, C., Corrado, D., Arnett, D., et al. (2006) Contemporary Definitions and Classification of the Cardiomyopathies. Circulation, 113, 1807-1816. https://doi.org/10.1161/CIRCULATIONAHA.106.174287

[35] Maron, B.J. and Maron, M.S. (2013) Hypertrophic Cardiomyopathy. The Lancet, 381, 242-255.

[36] Farb, A., Tang, A.L., Burke, A.P., Sessums, L., Liang, Y. and Virmani R. (1995) Sudden Coronary Death. Frequency of Active Coronary Lesions, Inactive Coronary Lesions, and Myocardial Infarction. Circulation, 92, 1701-1709. https://doi.org/10.1161/01.CIR.92.7.1701

[37] Perper, J.A., Kuller, L.H. and Cooper, M. (1975) Arteriosclerosis of Coronary Arteries in Sudden Unexpected Deaths. Circulation, 52, 27-33.

[38] Baroldi, G. (1965) Acute Coronary Occlusion as a Cause of Myocardial Infarct and Sudden Coronary Heart Death. The American Journal of Cardiology, 16, 859-880. https://doi.org/10.1016/0002-9149(65)90704-6

[39] Myers, A. and Dewar, H.A. (1975) Circumstances Attending 100 Sudden Deaths from Coronary Arterial Disease with Coroner's Necropsies. British Heart Journal, 37, 1133-1143. https://doi.org/10.1136/hrt.37.11.1133

[40] Loire, R. and Tabib, A. (1996) Mort Subite Cardiaque Inattendue. Bilan de 1000 Autopsies. Archives des Maladies du Coeur et des Vaisseaux, 89, 13-18.

[41] Chugh, S.S., Kelly, K.L. and Titus, J.L. (2000) Sudden Cardiac Death with Apparently Normal Heart. Circulation, 102, 649-654. https://doi.org/10.1161/01.CIR.102.6.649

[42] Huikuri, H.V., Castellanos, A. and Myerburg, R.J. (2001) Sudden Death Due to Cardiac Arrhythmias. The New England Journal of Medicine, 345, 1473-1482. https://doi.org/10.1056/NEJMra000650

[43] Myerburg, R.J. and Castellanos, A. (2005) Cardiac Arrest and Sudden Cardiac Death. In: Zipes, D.P., Libby, P., Bonow, R.O. and Braunwald, E., Eds., Braunwald $s$ Heart Disease. A Textbook of Cardiovascular Medicine, Elsevier Saunders, Philadelphia, 865-908.

[44] Chugh, S.S., Jui, J., Gunson, K., Stecker, E.C., John, B.T., Thompson, B., Ilias, N., Vickers, C., Dogra, V., Daya, M., Kron, J., Zheng, Z.-J., Mensah, G. and McAnulty, J. (2004) Current Burden of Sudden Cardiac Death: Multiple Source Surveillance Versus Retrospective Death Certificate-Based Review in a Large U.S. Community. Journal of the American College of Cardiology, 44, 1268-1275. https://doi.org/10.1016/j.jacc.2004.06.029

[45] Spain, D.M., Bradess, V.A. and Mohr, C. (1960) [L'athérosclérose coronaire en tant que cause de décès inattendu et inexpliqué. Une étude d'autopsie de 1949-1959]. Journal of the American Medical Association, 174, 384-388. 
https://doi.org/10.1001/jama.1960.03030040038010

[46] Manfredini, R., Portaluppi, F., Grandi, E., Fersini, C. and Gallerani, M. (1996) [Mort subite en dehors de l'hôpital faisant référence à un service d'urgence]. Journal of Clinical Epidemiology, 49, 865-868.

https://doi.org/10.1016/0895-4356(96)00114-X

[47] de Vreede, J.J.S., Gorgels, A.P., Dubois-Arbouw, W.I., van Ree, J.W., Daemen, M.J., Houben, L.G. and Wellens, H.J. (1997) Arrêts cardiaques hors hôpital dans les années 90: Etude de l'incidence, des caractéristiques et de la survie dans la région de Maastricht dans la région de Maastricht. Journal of the American College of Cardiology, 30, 1500-1505.

[48] Basso, C., Frescura, C., Corrado, D., Muriago, M., Angelini, A., Daliento, L. and Thiene, G. (1995) Congenital Heart Disease and Sudden Death in the Young. Human Pathology, 26, 1065-1072. https://doi.org/10.1016/0046-8177(95)90267-8

[49] Larson, E.W. and Edwards, W.D. (1984) Risk Factors for Aortic Dissection: A Necropsy Study of 161 Cases. The American Journal of Cardiology, 53, 849-855. https://doi.org/10.1016/0002-9149(84)90418-1

[50] Januzzi, J.L., Isselbacher E.M., Fatiori, R., Cooper, J.V., Smith, D.E., Fang, J.M., et al. (2004) Characterizing the Young Patient with Aortic Dissection: Results from the International Registral of Aortic Dissection (IRAD). Journal of the American College of Cardiology, 43, 665-669. https://doi.org/10.1016/j.jacc.2003.08.054 